\title{
CHALLENGES AND BARRIERS IN FORMATION OF COMMUNICATIVE COMPETENCE AMONG ENGLISH LANGUAGE LEARNERS
}

\author{
Bozhok O.I., Bilins'ka L.I. \\ Prydniprovs'k State Academy of Civil Engineering and Architecture
}

Gomola M.M.

Alfred Nobel University

\begin{abstract}
DOI: https://doi.org/10.32839/2304-5809/2018-12-64-93
\end{abstract}
The aim of this research is to highlight some problems in teaching and learning English as a foreign language. As there exist different ways in mastering foreign languages there also exist many methods of their teaching. In the course of training many students face with spelling, inflection, pronunciation, grammar and other common problems which are constantly investigated and solved. According to the level of any individual group of students the approach of organization and conduction of the lesson should also be individual as learners make different mistakes. So teachers of any foreign language must not just get formal education but also be aware of modern techniques and approaches.

Keywords: mistakes, challenges in learning, methods and approaches, teachers and learners, foreign language, objective, mastering, accumulating, level, difficulties.

$\mathrm{F}$ Tormulation of the problem in general. Modern society requires its members to possess at least one foreign language and usually it is English. But in practice it isn't an easy task as for teachers and learners. To obtain foreign language you must spend many days, months and years. Nowadays you cannot succeed in your career if you don't know any foreign language. You will not be able to exchange information, experience and knowledge with colleagues from other countries without the understanding of each other. In your work you can get many useful things while using foreign sources of information that make your environment wider.

It is no wonder that the English language is very popular now and has become something of a forerunner in global communication. Most people in different countries of the word choose it for their mastering. This language is widely used in computer sciences, programming, economics, medicine, construction and space programs. English is the language of prominent scientists, writers, politicians, musicians and sportsmen such as Thomas Cromwell, Sir Isaac Newton, Lord Nelson, Sir Winston Churchill, Roger Bacon, Sir Christopher Wren, Jonathan Swift, Adam Smith, John Ford, Oscar Wilde, Sir Richard Burton, Indira Gandhi and of course many others. So if you want to find common language with other people and society as a whole you have to know at least one foreign language [2].

The conversation between two strangers usually begins with such phrases as "Do you speak English?", "Sprechen Sie Deutsch?", "Parlez-vous français?" and the most common answer that you can hear will be "Yes, I do". This situation shows that most people speak or at least understand English.

Hence, the knowledge of English language occupies an important role in bringing people together. Thus, many scholars pay a grate attention to the problem of training English to young specialists who find English hard to learn.

Analysis of recent researches and publications. In the light of well-known circumstances and recent events present day society should pay serious attention to the development of international re- lations with other nations. In our age of wholesale computerization, advanced technologies and scientific progress the necessity to gain the required skills of English as an international language has become of prime importance for students and teachers. Because of this tendency a great many of outstanding scientists and scholars such as V. Humboldt, M. Berlitz, M. Walter, F. Huen, V. Fiester, P. Passi, L. Scherba, E. Ryt, L. Blumfild, Ch. Fries, I. Rakhmanov, I. Bim, A. Leontiev, I. Kolesnikova, O. Dolgina, M. Lyakhovitskiy, E. Passov, E. Kuznetsova, P. Gritsenko, A. Zagnitko, A. Zelenko, V. Moskvin, N. Ozerova, V. Rybalkin, K. Tischenko, I. Farion, A. Chirkov, turned to the investigation of challenges which always take place while learning English as the second language. Many educational establishments tend to enlarge the number of language training hours but pupils and their teachers faced with some circumstances which showed that some methods and approaches didn't correspond to ever changing demands of the time. Even after years of study it has become clear that it is quite difficult to learn foreign language effectively and even most of hardworking students are not satisfied with their skills in English.

The purpose of this research. The aim of the article is to highlight some peculiarities in the English language that complicate learning. As students' abilities differ so different can be their problems. Along with students many teachers involved in to the process of education find out that some changes are necessary according to the latest norms and demands.

The main material of investigation. The research shoes that there exist multiple difficulties in spelling, inflection, approach, pronunciation, grammar, orthography and so on. There are many reasons for this. Let us look at some of them:

- Spelling: If we compare the English language with some other languages (German as an example) we can find that the spelling manner of many words may be catchy to muster. We want to assure you that while learning English it is not always reliable to refer to phonetics as very often pronunciation and spelling of practically similar words may 
have deep differences. English grammar contains many rules that direct language learners how to wright and pronounce some English words and expressions correctly but there exist a lot of exceptions to learn. Full awareness in pronunciation of the word does not give you assurance in its correct writing. Here are several common examples:

1. dew/ do/ due: dew (іменник) - poca. (Very often in summer you can notice the dew outdoors.); to do (дієслово) - робити. (They usually do their homework in the afternoon.); due (прикметник) належний, зобов'язаний (за згодою). (He is due to speak at the meeting.)

2. know/ no: to know (дієслово) - знати, вміти. (I know him very well.); nо (заперечна частка) - ні (They have no idea about their summer holidays.)

3. pair/ pear: pair (іменник) - пара. (Where can I buy a pair of trousers?); pear (іменник) - груша. (I like pears most of all.)

4. to/ too/ two: to (прийменник) - до, в, на. (The windows look to the south.); too (прислівник) теж, дуже, занадто, дійсно. (Won't you come too?); two (числівник) - два. (That makes two of us.)

5. wear/ where: to wear (дієслово) - носити одяг. (Why did you wear this raincoat?); where (питальне слово) - де, куди. (Where do you go?)

6. knight/ night: knight (іменник) - лицар. (The film "Knights" is very interesting.); night (іменник) - ніч. (Children must sleep at night).

Even people who consider that they speak the same "English language" but live on a large distance from each other pronounce the same words differently due to historically rooted events and this even often complicates the notion of learning English as the second foreign language.

- Inflection: Those who want to enlarge their competence in some aspects of the English language learning must pay attention to such notion as inflection as the meaning of the sentence can be changed considerably depending on the place of your inflection in it. For instance, in the sentence "They prefer to read novels." stressing the word "read" tells you what the person likes to do, while stressing the word "novels" tells you what the person reads. There is another example in which stressing different parts of the sentence you can get another meaning of it: "I didn't mean we should buy this car." If you stress "I", you accentuate that purchasing that car wasn't your idea. On the other hand, if you underline "buy" you emphasize the mode of action. And vice versa the person talking to you can misunderstand you if you don't inflect your expression at all. You can completely change the meaning of the sentence simply shortening the word, pronouncing it silently or slightly louder or altering the timbre of your voice. From this we can conclude that inflection in the speech plays very significant role [5].

- Approach: There is one more problem in learning English and it is connected with some kind of fright. This can be easily explained by historical events. For many centuries Great Britain dominated on many continents because of its numerous colonies and local population (rulers, sailors, craftsmen, traders, farmers) had to learn English to communicate with British conquerors. In the result of such "cooperation" both sides revealed many benefits for their culture, education, economy and industry
[4, p. 5-10]. Hence people have found the advantage of knowing English that led them to prosperity and wellbeing on most territories of British post dominance. Thus the fair of handling English as the foreign language disappeared.

- Pronunciation: A key stone in learning any foreign language is correct pronunciation that is the manner in which you make the sound of words while speaking [6, p. 25]. The students who start to speak English or any other foreign language have many problems with their pronunciation of some sounds which every language contains. Mistakes in pronunciation can cause misunderstanding you by native or other speakers of the English language as many English sounds and orthographic rules have a very strong influence on our pronunciation. So let us highlight this problem more detailed in some examples:

$\mathrm{TH}$ : According to the rule th is pronounced as $/ \theta /$ or $/ ð /$ but many students pronounce it mistakenly as /t/ and /d/ or the sounds " $t$ " and "s". This occurs because of the influence of student's native language that can make even a funny situation (They sink that you are thinking). There are some common problematic words: thick, sick; think, sink; thick, tick; this, diss.

$\mathrm{CH}$ : As it is known ch is commonly pronounced as "ch" in "chest", "chess", "chin", but there are other cases when ch can sound as "k" in "karri" (ache, character, chemistry, mechanism, school, monarch, technology) or even "sh" as in "shift" (chef, charade, machine, parachute, chauffeur, moustache). Such variations in pronunciation can lead to some difficulties amidst students who start to learn English [6, p. 30].

$\mathrm{V}$ and W: Very often the letters "v" and "w" are pronounced similarly according their natural likeness and this is a sort of mistake both in speaking and reading. The correct pronunciation of these two letters is especially essential if we pay attention to the following examples where wrong articulation may lead to misunderstanding: wet vet [wet] - [vet] (сирий - ветеринар); wail - veil [weil] - [veil] (завивання - вуаль), wheel - veal [wi:l] - [vi:1] (колесо - телятина); west - vest [west] - [vest] (захід - жилет).

$A$ and E: In the English language such sound as /æ/ can be expressed by two letters "a" and "e" depending on the length of pronunciation. As in the previous case the incorrect articulation of the middle vowel /æ/ leads to confusion in conversation. This is clearly seen in the following illustration: said - sad [sed] - [sæd] (сказав - сумний); bed - bad [bed] - [bæd] (ліжко - поганий); pen pan [pen] - [pæn] (ручка - каструля); lend - land [lend] - [lænd] (позичати - земля); send - sand [send] - [sænd] (посилати - пісок).

Vowel length: There is a basic tendency among learners to mispronounce some English words in which the length of vowels plays a great role. This means that while speaking you can change the sense of the word in its entirety and such mistake in articulation, of course, can misrepresent the whole expression. At our classes we always emphasize the importance of vowel length in short and long pronounced words as it is easier to remember them while reading because of the difference in their spelling. To speak them correctly we need to devote more time and efforts practicing 
them. And that is why it is even necessary to give students such problematic words in the form of the table or list to master the rulers of their proper pronunciation. To see the full essence of this problem let us look through some examples: full - fool [ful] - [fu:l] (повний - дурень); live - leave [liv] [li:v] (жити - залишати); cut - cart [kst] - [ka:t] (різати - віз); this - these [ðiz] - [ði:z] (цей - ці) seek - sick [si:k] - [sik] (шукати - хворий); rich reach [ritf] - [rı:tf] (багатий - досягти); leak - lick [li:k] - [lik] (витік - лизати) [3, p. 91-92].

Word stress: There is one more notion in English grammar when beginners muddle up the position of the word stress that changes its right meaning. Very often it relates to English homographs (two-syllable verbs and nouns). If we take into account some examples we can see that in nouns the stress falls on the first syllable but in verbs on the last: 'ex-port (експорт) - ex-'port (експортувати); 'in-crease (збільшення) - in'-crease (збільшувати); 're-cord (реєстр) - re-'cord (реєструвати); 'su-spect (підозрюваний) - su-'spect (підозрювати); 'pro-duce (продукція) - pro-'duce (виробляти); 'in-sult (образа) - in-s'ult (ображати); 'con-duct (поведінка) - con-'duct (проводити).

Mixing up letters: English language teachers should not fail to take this aspect into account as the problem of pronunciation of similarly sounding letters confounds even those whose native language is English. Some neighboring letters and letter combinations especially $\mathrm{L}$ and $\mathrm{R}$; $\mathrm{B}$ and $\mathrm{P}$; $\mathrm{F}$ and $\mathrm{T} ; \mathrm{T}$ and $\mathrm{TH} ; \mathrm{S}$ and $\mathrm{SH}$ cause difficulties in articulation of some words, word combinations and even sentences [6, p. 28]. You may improve your pronunciation while practicing some famous tongue twisters: The shells she sells are sea-shells, I'm sure. That's what made these three free fleas sneeze. Through three cheese trees three free fleas flew. Most camera colors are rather of lower vibrancy in the real world. A peck of pickled peppers Peter Piper picked. But a bit of better butter makes better batter.

As you can see there exist difficulties and mistakes in pronunciation but they differ from one another. Some of them are noticeable while others do not play significant role.

- Grammar: English language teachers emphasize another problem that concerns some grammar rules. Each foreign language contains a large number of peculiarities in grammar and English is not an exception. Much attention must be payed to these difficulties as its grammar represents the main sticking point in acquiring this language properly. You can speak English fluently, understand your interlocutor, you can listen and hear but while writing it will become evident your incompetence in some grammar regulations.

The learners of any foreign language find it difficult to accommodate some unusual criteria in the usage of tenses and sentence structure (for example). Language teachers also denote that their pupils often make mistakes in such aspects of foreign grammar rules that are not natural for their native ones [1, p. 70]. This can refer to articles (definite or indefinite) and their position, singular or plural number of the nouns, degrees of comparison of the adjectives and adverbs (incomplete comparisons), problems with prepositions and pronouns.
Many students also don't completely understand the sense of verb tenses as many of them don't have clear limits of their application (even native speakers have no need to use all of them) not to mention different variants of the English language. This list can be very long therefore let us pay attention to the most common grammar challenges:

1. Location of apostrophes in the wrong place is one of the widespread grammar mistakes in the English language. If we want to indicate singular or plural possession we put apostrophe before or after "s". Wrong: This is my fathers car. Correct: This is my father's car. Wrong: Students test papers were in the classroom. Correct: Students' test papers were in the classroom. In order to make plural forms we shouldn't use apostrophes. Wrong: Her dog's are in the yard now. Correct: Her dogs are in the yard now [3, p. 128].

2 . Some people often confuse the difference of the words "fewer" and "less" as "fewer" is used with countable nouns and "less" with uncountable. Wrong: He has less mistakes in the composition. She used fewer butter in the cake than it was necessary. Correct: He has fewer mistakes in the composition. She used less butter in the cake than it was necessary [3, p. 110-113].

3 . When you compare something with something don't forget about the object of your comparison. Wrong: Most buildings in our city are more beautiful and modern. Correct: Most buildings in our city are more beautiful and modern than those in the capital of the country [3, p. 32-33]

4. Sometimes learners have problems with the meaning and correct usage of "Who", "Whom" and "Whose". "Who" denotes a living pronoun. "Whom" means the recipient of something. "Whose" indicates ownership to somebody. Correct: Who lives in this house? - My uncle does. / Whom did you send the letter? - To my sister. (Whom did you invite to the party? - All my best friends were invited.) / Whose car is this? - This is my father's car [3, p. 30-31].

5. Many languages don't have such notion as articles. But English definite and indefinite articles occupy noticeable place in grammar. When we mean something that is unfamiliar to the speakers, we use "a"; but if we have some information about the object of the speech, we use "the". Correct: Take an apple (we mean any apple you like). / Take the apple that is on the table (we mean definite apple) [3, p. 53].

6 . Very often such prepositions as at, for, in, on are not used in a proper way by non-native speakers as they adopt them to their own language. Here are some common examples. Wrong: There were many pupils in our school. Correct: There were many pupils at our school. / Wrong: We have math in Monday. Correct: We have math on Monday. / Wrong: All my friends have been living here since ten years. Correct: All my friends have been living here for ten years. / Wrong: We don't use to walk in the night. Correct: We don't use to walk at night [3, p. 83-87].

Developing the structure of each lesson English language teacher should pay attention to proper organization of the students' work concerning their abilities to perceive and master all kinds of activities such as reading and speaking, accumulating of written and spoken communicative activities 
[1, p. 81]. To maintain favorable and creative atmosphere at the classes teachers ought to prompt their students not to fair make mistakes and keep on learning the language and practicing it. To overcome the most common grammar or lexical difficulties it is necessary to practice your language while communicating to native speakers or at least to hear how the language is used in everyday life. Besides this it will be useful to participate in their cultural life through watching English channels, listening to music or reading English literature.

Conclusions. Our research emphasizes the evident importance of ever-existing "blank spots" in the methods of teaching practices which we should take into consideration and eliminate them. For sure a good command of languages cannot guarantee a proper application of it while teaching process. Even not every native speaker will be able to organize methodical and intensive training course in comparison with a highly qualified and experienced English language teacher who is in constant search of not just new but also advanced and most effective methods. Some skills concerning the vision and determining the most common challenges in acquiring any foreign language give us (teachers) the possibility to overcome them correctly and painless to channel the learners into the right direction.

In our research we also wanted to show that the existence of such aspect as application of communicative approach only would not be effective and even erroneous. Most students are inclined to make mistakes in such situations that other find them inadmissible. The task of teachers is always to be ready to the most unusual and unexpected circumstances at the lesson and be able to handle them with dignity.

The importance of our research is in its constant development. Time passes but problems remain the same and their continuous investigation will give us new perspectives and opportunities of their successful solution.

\title{
References:
}

1. Al-Mekhlafi M.A., Nagaratnam R.P. Difficulties in teaching and learning grammar in an EFL context / M.A. AlMekhlafi, R.P. Nagaratnam // International Journal of Instruction. - 2011. - Vol. 4. - № 2. - P. 69-85.

2. Rani K.J. Teaching and Learning English as a Foreign / Second language: Importance of Learning Strategies / K.J. Rani // International Journal on English Language and Literature. - 2013. - Vol. 1. - № 1. - P. 96-98.

3. Fitikides T.J. Common mistakes in English / T.J. Fitikides. - Longman, 2002. - 189 p.

4. Léglise I., Migge B. Language and colonialism. Applied linguistics in the context of creole communities / I. Léglise, B. Migge // Handbooks of Applied Linguistics. - 2007. - Vol. 9. - P. 297-338.

5. Blevins J.P. English Inflection and Derivation / J.P. Blevins // The Handbook of English Linguistics. - 2006. Chapter 22. - P. 507-536.

6. Singh P. Spelling and Pronunciation Errors in English Language / P. Singh // International Journal of Educational Research and Technology. - 2017. - Vol. 8. - P. 25-31.

Божок О.І., Білінська Л.І.

Придніпровська державна академія будівництва та архітектури

Гомола М.М.

Університет імені Альфреда Нобеля

\section{ПРОБЛЕМИ ТА БАР'СРИ У ФОРМУВАННІ КОМУНІКАТИВНОЇ КОМПЕТЕНЦІЇ СЕРЕД ВИВЧАЮЧИХ АНГЛІЙСЬКУ МОВУ ЯК ІНОЗЕМНУ}

\begin{abstract}
Анотація
Метою цього дослідження є висвітлення деяких проблем у викладанні та вивченні англійської мови як іноземної. Оскільки існують різні способи оволодіння будь-якими іноземними мовами, також існує багато методів їх вивчення. У процесі підготовки багато студентів стикаються з проблемами правопису, перекладу, вимови, граматики та іншими загальними проблемами, які постійно досліджуються та вирішуються. Відповідно до рівня будь-якої індивідуальної групи студентів, підхід до організації та проведення уроку повинен також бути індивідуальним, оскільки учні роблять різні помилки. Тому вчителі будь-якої іноземної мови повинні не просто отримати спеціальну освіту, а й бути в курсі сучасних методів та підходів.
\end{abstract}

Ключові слова: помилки, проблеми в навчанні, методи та підходи, вчителі та учні, іноземна мова, ціль, освоєння, накопичення, рівень, труднощі. 
Божок А.И., Билинская Л.И.

Приднепровская государственная академия строительства и архитектуры

Гомола М.Н.

Университет имени Альфреда Нобеля

\title{
ПРОБЛЕМЫ И БАРЬЕРЫ В ФОРМИРОВАНИИ КОММУНИКАТИВНОЙ КОМПЕТЕНЦИИ СРЕДИ ИЗУЧАЮЩИХ АНГЛИЙСКИЙ ЯЗЫК КАК ИНОСТРАННЫЙ
}

\begin{abstract}
Аннотация
Целью данного исследования является освещение некоторых проблем в преподавании и изучении английского языка как иностранного. Поскольку существуют разные способы овладения иностранными языками, существует также много способов их преподавания. В ходе обучения многие студенты сталкиваются с орфографрическими, интонационными, грамматическими, трудностями в произношении и другими проблемами, которые постоянно исследуются и решаются. В зависимости от уровня отдельно взятой группы студентов подход к организации и проведению урока должен быть индивидуальным, так как учащиеся допускают разные ошибки. Поэтому учителя любого иностранного языка должны получать не только специальное образование, но и знать современные методы и подходы.

Ключевые слова: ошибки, проблемы в обучении, методы и подходы, учителя и ученики, иностранный язык, цель, усвоение, накопление, уровень, трудности.
\end{abstract}

